\title{
Instructional Design: Multi-Site Study of the Integration of Islam in Science Teaching in Java, Indonesia
}

\author{
Abd. Ghofur ${ }^{1}$, Joel C. Kuipers ${ }^{2}$, Askuri ${ }^{3}$ \\ ${ }^{1}$ Universitas PGRI Adi Buana Kampus Lamongan ${ }^{2}$, George Washington University, \\ Washington DC, USA ${ }^{3}$, Universitas 'Aisyiyah Yogyakarta \\ 1'ghofurkita@yahoo.com, ${ }^{2}$ kuipers@gwu.edu, ${ }^{3}$ asykuri@yahoo.com
}

\begin{abstract}
This study aims to describe the baseline of instructional strategies currently deployed by teachers in the form of goal setting, media selection, application of methods, and evaluation of learning in relation to Islamic values in science teaching. This research was designed in the form of a qualitative description by involving 18 Islamic schools spread over three regions in Indonesia, namely Malang, Lamongan, and Yogyakarta. Methods of data collection used observation forms, ethnographic video during the learning process, interviews with education stakeholders, Forum Group Discussion (FGD) with students, and documentation study for 6 months. Although Islamic schools in the selected study areas in Java, Indonesia have embraced the integration of Islam into science teaching, as mentioned in the Core Competencies [KI] in the National Curriculum 2013), however, the implementation of it is still not optimal. In addition, the integration of Islam in science teaching is mostly done by teachers through lecture methods. While most teachers expressed interest in the integration of Islam and science, many teachers expressed anxiety about their competence in addressing complex theological issues. The majority of science teachers in Islamic schools have similar strategies in developing ways to integrate the science curriculum. One key strategy is to browse online and find verses from the Qur'an that seem relevant to the lesson.
\end{abstract}

\section{Keywords: Design of Science Teaching, Integration of Islam, Islamic School}

\begin{abstract}
Abstrak
Kajian ini bertujuan untuk mendeskripsikan baseline strategi pembelajaran yang saat ini diterapkan oleh guru dalam bentuk penetapan tujuan, pemilihan media, penerapan metode dan evaluasi pembelajaran dalam kaitannya dengan nilai-nilai dalam pembelajaran IPA. Penelitian ini dirancang dalam bentuk deskripsi kualitatif dengan melibatkan 18 sekolah Islam yang tersebar di tiga wilayah di Indonesia, yaitu Malang, Lamongan, dan Yogyakarta. Metode pengumpulan data menggunakan formulir observasi, video etnografis selama proses pembelajaran, interview dengan stakeholder pendidikan, FGD dengan siswa, dan kajian dokumentasi selama 6 bulan. Meskipun sekolah Islam di wilayah studi terpilih di Jawa, Indonesia telah menganut integrasi Islam ke dalam pengajaran sains, sebagaimana disebutkan dalam Kompetensi Inti (KI) dalam kurikulum nasional 2013, namun implementasinya masih belum optimal. Selain itu, integrasi Islam
\end{abstract}


dalam pengajaran sains banyak dilakukan oleh guru melalui metode ceramah. Sementara sebagian besar guru menyatakan minatnya pada integrasi Islam dan Sains, banyak guru mengekspresikan kecemasan tentang kompetensi mereka dalam menangani masalah teologis yang kompleks. Mayoritas guru IPA di sekolah Islam memiliki kesamaan strategi dalam mengembangkan cara untuk mengintegrasikan kurikulum IPA. Salah satu strategi utamanya adalah dengan menelusuri secara online dan menemukan ayat-ayat Al-Qur'an yang tampaknya relevan dengan pelajaran.

\section{Kata Kunci: Desain Pengajaran Sains, Integrasi Islam, Sekolah Islam}

\section{Introduction}

Indonesia is the country with the largest Muslim population in the world. According to the results of the presentation of ibtimes.id, it is explained that the Muslim population in Indonesia is around 229 million. This means that $87.2 \%$ are Muslims of Indonesia's population of 263 million, or around 13\% of the world's Muslim population. In addition, Islam in Indonesia is also experiencing developments in almost all areas of life. ${ }^{1}$ For example, in the field of Muslim fashion presented by Nisa and Rudianto, they state that Muslim fashion develops with a variety of creations that are in accordance with Islamic law and remain trendy. ${ }^{2}$ Many other fields have also developed because of the nuances of Islam in them, including Islamic art, ${ }^{3}$ then the Islamic lifestyle, ${ }^{4}$ and so on. Although there are few outbursts of violence in the name of Islam, the resurgence of the world's largest Muslim nation shows a modern, educated, prosperous, tolerant, moderate Muslim society symptom, has been fully prepared for globalization.

The phenomenon of Islamization in Indonesia also began to be associated with the discourse of science. For example, the existence of a community calling itself as the Flat Earth (Flat-Earth Community). This community promoted that the earth round is just an illusion and lie. The satellite imagery that reveals the earth is round is merely engineering and conspiracy. This group even reinforces their beliefs with the religious arguments of the scriptures: And We have spread the earth, and we have planted mountains, and we have grown there by measure (Qur'an, 15:19).

\footnotetext{
${ }^{1}$ Yahya Fathur Rozy, "Data Populasi Penduduk Muslim 2020: Indonesia Terbesar Di Dunia,” Ibtimes.id, 2020, https://ibtimes.id/data-populasi-penduduk-muslim-2020-indonesia-terbesar-di-dunia/.

${ }^{2}$ Nisa Khairun and Rudianto, "Trend Fashion Hijab Terhadap Konsep Diri Hijabers Komunitas Hijab Medan," Jurnal Interaksi 1, no. 1 (2017): 105-17.

${ }^{3}$ A Heryanto, Identitas Dan Kenikmatan: Politik Budaya Layar Indonesia (Jakarta: Kepustakaan Populer Gramedia, 2015).

${ }^{4}$ C Jones, "Images of Desire: Creating Virtue and Value in an Indonesian Islamic Lifestyle Magazine," Journal of Middle East Women's Studies 6 (2010): 91-117.
} 
The disruption of the meaning of this science discourse associated with the religious arguments was lively discussed in social media. While this was only a misunderstanding, it gained wide attention from many netizens. This opinion was debatable. For those who believe in this opinion, they only relied on religious fanaticism without seeing the contextualization of the proposition of al-Qur'an which is the basis of the science discourse. But for those who are knowledgeable do not certainly necessarily believe in that opinion as a truth. They believe that the Qur'anic verses that justify the beliefs of the Flat-Earth community are in fact mistaken and tend to be twisted arbitrarily because the true teaching of Islam fit the findings of modern science. Indeed, the Qur'an does not explicitly explain that the earth is round, but thousands of years ago Muslim scholar al-Biruni had already assured that the earth is round. Even. Al-Biruni had estimated the circumference of the earth's circumference accurately over 40,075 kilometers, almost exactly accurate with the calculations of modern science. Many blogs also defend the Qur'an and the truth of science: the words used to describe the earth in the Qur'an tend to be that the shape of the earth is round.

In the book "When Science Meets Religion", Ian Barbour presents four typologies on how to connect science and religion: ${ }^{5}$ (1) Conflict - where the two fields are considered contradictory to one another; (2) Independence - in which the two fields are not interrelated. (3) Dialogue - in which the two fields engage in dialogue about similarities and differences in methods and approaches; (4) Integration - in which the two fields try to attract each other to understand, test, confirm or interpret each other's claims.

Religion is often associated with science. Related to this, ${ }^{6}$ conducted a study entitled The Relationship between Science and Religion: A Philosophical Reflection on Ian G. Barbour's Thought. There are 4 typologies of the relationship between religion and science. First, conflict typology, where the two fields are considered contradictory to one another, which involves scientific materialism and biblical literalism. (2) Independent typology, in which the two fields are not interrelated, namely separating the two types into two different areas. Both can be distinguished based on the problem under study, the domain they refer to, and the methods (existentialism and neoorthodoxy) used and the two languages and their two different functions (analytical

\footnotetext{
${ }^{5}$ Ian G Barbour, When Science Meets Religion (New York: Harper San-Fracisco, 2000).

6 Waston, "Hubungan Sains Dan Agama: Refleksi Filosofis Atas Pemikiran Ian G. Barbour," PROFETIKA, Jurnal Studi Islam 15, no. 1 (2014): 76-89.
} 
tradition) (3) Typology of dialogue, in which the two fields engage in dialogue about similarities and differences in methods and approaches, namely those that consider presuppositions in scientific efforts, or explore the alignment of methods between science and religion, (4) Integration, in which the two fields try to attract each other to understand, test, confirm or interpret each other's claims, which consists of natural theology, theology of nature, systematic synthesis (science or religion contributes to the development of inclusive metaphysics such as Whitehead's process philosophy theology).

Since 2014, Indonesian schools - both general and religious school based, have enacted the Curriculum 2013. The curriculum provides a broad opportunity for civil society's participation to color science teaching, one of which is religious spirit, by enacting the first core competence of religious attitudes. Of course, it is increasingly open opportunities for Islamic integration into science teaching. Islamic organizations that run education, such as $N U$ and Muhammadiyah, have long desired the integration of Islam in science teaching. In fact, today more and more Islamic schools are promoting and labelling themselves as schools that integrate Islam and science under the name "Integrated Islamic School", but without clear concept or implementation.

Science has a space of study that can be observed directly by the five senses and is limited to things that can be observed. Therefore, the objects of modern scientific study consist of matter, living things, thoughts, natural culture and history. ${ }^{7}$ In addition, scientific literacy will have an impact on the development of students' thinking skills as part of the components of Life Skills. ${ }^{8}$ Science and religion are one unit, where the difference between the two lies only in their perspective. ${ }^{9}$ Both are sourced from god used by humans to live life.

The integration of Islam in science teaching is certainly possible, considering many phenomena of science discourse using the religious arguments that would be dangerous for the laity. Educational institutions are the best place to embed the concept of Islamic integration in science teaching. Because according in his book the reasoning of the verses of the universe that there are more than 800 verses in the Qur'an related to

\footnotetext{
7 Misbah Khoiruddin Zuhri, "Spiritualitas Sains Modern: Pembacaan Terhadap Relasi Agama Dan Sains," JURNAL PENELITIAN 14, no. 2 (2017): 183-200.

8 Iing Dwi Lestari, "Pengaruh Literasi Sains Terhadap Kemampuan Kognitif Siswa Pada Konsep Ekosistem," Prosiding Seminar Nasional Pendidikan FKIP UNTIRTA 2017, 2017, 103-6.

9 Nur Hasanah and Anggun Zuhaida, "Desain Madrasah Sains Integratif: Integrasi Sains Dan Agama Dalam Perangkat Dan Pelaksanaan Pembelajaran," Edukasia : Jurnal Penelitian Pendidikan Islam 13, no. 1 (2018): 155, https://doi.org/10.21043/edukasia.v13i1.3517.
} 
science. ${ }^{10}$ It is also reinforced by the Ministry of Religion's explanation that there are about 750-1000 verses in al-Qur'an discussing science.

The integration of Islam in science education is important in educational institutions, considering the number of Islamic schools in Indonesia is very large. Based on data from the Ministry of Religious Affairs (2016) the number of Islamic educational institutions Islamic Kindergarten (RA) level of 27.9 thousand, Islamic Primary School (MI) as many as 24.5 thousand, Islamic Junior Secondary School (MTs) of 29.9 thousand, and Islamic Senior Secondary School (MA) as much as 7.8 thousand. Not to mention Islamic-based colleges also occupy the largest number in the world. Therefore, to study about how the pattern of integration of Islam in science teaching is designed by teachers in Islamic schools becomes important to conduct. According to instructional design is a design in which it is in the form of a series systematic procedures cover the entire learning process from start to finish by collaborating theories, models and learning media according to the material so produce learning tools. In addition, learning design is also a formulation in which there is a process based on the desired learning objectives achieved. ${ }^{11}$ Meanwhile, according to instructional design is a grating of the application of learning and learning theories to facilitate one's learning process. ${ }^{12}$ The purpose of the Instructional design is to make learning more effective and efficient and reduce the difficulty level of learning. ${ }^{13}$ Therefore, designing learning becomes an important part of the process of achieving learning objectives. ${ }^{14}$ However, based on research results, the fact is that the development of learning designs has not been carried out optimally. ${ }^{15}$ One of the reasons is the lack of teacher understanding of the learning design so that the learning process is adjusted to the student books which may not be in accordance with the characteristics of students in the classroom. ${ }^{16}$

\footnotetext{
${ }^{10}$ Agus Purwanto, Nalar Ayat-Ayat Semesta (Bandung: Mizan, 2015).

${ }^{11}$ N Lubis, M. A. \& Azizan, Pembelajaran Tematik SD/MI (Yogyakarta: Samudra Biru, 2019).

12 Charles M Reigeluth, "Instructional Theory and Technology for the New Paradigm of Education," Revista de Educación a Distancia, no. 50 (2016): 1-18, https://doi.org/10.4324/9781315760933.

13 \& Jerrold E. Kemp Gary R. Morrison, Steven M. Ross, Howard K. Kalman, Designing Effective Instruction 7th Edition (Indiana: Jon Wiley \& Sons.Ind., 2013).

14 Trisna Amelia and Inelda Yulita, "Desain Pembelajaran Berbasis Literasi Sains Dan Berwawasan Kemaritiman Sebagai Hasil Pelatihan Di SMAN 4 Tanjungpinang," Jurnal Anugerah 1, no. 1 (2019): 2531, https://doi.org/10.31629/anugerah.v1i1.1580.

${ }^{15}$ S I Gustina, Pengembangan Desain Pembelajaran Tematik Outdoor Permainan Tradisional Berbasis STEM Di Sekolah Dasar (Universitas Pendidikan Indonesia Kampus Tasikmalaya, 2018).

${ }^{16}$ Nida Oktapiani and Ghullam Hamdu, "Desain Pembelajaran STEM Berdasarkan Kemampuan 4C Di Sekolah Dasar," Jurnal Ilmiah Pendidikan Dasar 7, no. 2 (2020): 99, https://doi.org/10.30659/pendas.7.2.99-108.
} 
In accordance with the explanation above, then also explains that Instructional design is a procedure used to carry out the learning process. Developing a learning design, in fact, is not easy, and not as simple as we imagine. On a micro scale, the learning design model serves as a tool and guide to deliver students according to the expectations and ideals of society. Therefore, the process of designing and designing a learning design must pay attention to the prevailing value system and the changes that occur in that society. In addition, the learning design model must also pay attention to all aspects that occur to students. The development of technology and community culture is the fundamental reason why the development of instructional design needs serious attention. ${ }^{17}$

The integration of Islam and Science is an interesting study in learning activities, especially in Islamic schools. This is based on the number of Islamic schools on the island of Java, which of course teach a lot of religious lessons. This is also a concern of teachers when teaching science to their students to integrate materials related to Islam. The learning design carried out by Islamic school teachers is one illustration of how science learning is taught. Based on these descriptions, this article attempts to examine in depth through field research related to instructional design undertaken by teachers in integrating Islam in science teaching that they teach to their students in Islamic schools in Indonesia.

\section{Methods}

This study was designed using a qualitative descriptive method. According to Sugiyono, qualitative research is a research method based on the philosophy of positivism, used to examine the condition of natural objects, where the researcher is the key instrument, the sampling of data sources is done purposively and snowball, the collection technique is triangulation, the data analysis is inductive/qualitative, and qualitative research results are more important than generalizations. ${ }^{18}$ This type of research aims to determine the design of learning, both in the form of setting goals, using learning methods and media, as well as evaluating learning carried out by science teachers in integrating Islamic values in grade I students in Islam. junior high school

\footnotetext{
${ }^{17}$ Muhammad Andi Isya', "Pengembangan Model Pembelajaran Instruksional Design Dengan Model Addie Mata Pelajaran PAI Pada Materi Mengulang-Ulang Hafalan Surah Al Ma'un Dan Al Fil Secara Klasikal, Kelompok Dan Individu Kelas V SDN Gedongan 2 Kota Mojokerto," Ta'dibia: Jurnal Ilmiah Pendidikan Agama Islam 7, no. 1 (2017): 71, https://doi.org/10.32616/tdb.v7i1.37.

${ }^{18}$ Sugiyono, Metode Penelitian Kuantitatif, Kualitatif, $R \& D$ (Bandung: CV. Alfabeta, 2017).
} 
education level in Indonesia, approximately 12 to 13 years old. Data collection methods used observation forms, ethnographic videos during learning, interviews with education stakeholders, Forum Group Discussions (FGD) with students and study documentation for 6 months. The data were analyzed descriptively based on the information obtained during the field research.

This preliminary research was conducted in 18 (eighteen) madrasas in Indonesia spread over three regions, namely Lamongan, Malang, and Yogyakarta, each representing the north, south, and east of Java geographically, which were selected by purposive sampling technique. This is as Sugiyono's opinion that in qualitative research, the most frequently used sampling technique is using purposive sampling. Purposive sampling is a sampling technique of data sources with certain considerations, for example, the person is considered to know best about what we expect. ${ }^{19}$ This is what the researchers chose to choose schools in the three regions on the island of Java as research subjects. The schools selected as samples in this study took into account the distribution of the school area, the acquisition of school accreditation and the representation of the cooperation of school religious organizations. This is important because the background of the school and its area has a strong influence on decision making and policies implemented in the school. In addition, the representation between schools in urban areas and schools in districts is also used as a consideration in determining the research location. This study involved 19 teachers, 18 principals and 450 students as well as education stakeholders in their respective areas. This is done to find out how the role of policy makers and the extent to which the integration of Islamic values in science education is regulated.

\section{Discussion}

The science literacy skills of Indonesian students are very low, according to a survey conducted at 2015 by Trends in International Mathematics and Science Study (TIMMS) placed Indonesia in the lowest category of 40 countries. Other facts from the results of the Program for International Student Assessment (PISA) also indicate the ability of Indonesian students is still relatively low. The average score of achievement of Indonesian students for science is ranked 62 out of 69 countries evaluated. ${ }^{20}$ Among

\footnotetext{
${ }^{19}$ Sugiyono.

20 Abdul Ghofur, Nahdia Rupawanti Br, and Abdul Kholid Achmad, "Instructional Management Strategy: A Multi-Sites Study on Science Teaching for Islamic School” 3, no. 3 (2017): 211-17.
} 
the least prepared of all Indonesian students are those who attend religious schools (pesantren, madrasah, etc.) who have just adopted the national curriculum. After centuries learning only the Qur'an, pesantren and other schools have increasingly adopted the national curriculum, which has since evolved into the Curriculum 2013. In this curriculum, teachers are no longer considered knowledge conveyors (knowledge spreaders), but "facilitators" for students to build their own knowledge in an integrated way.

This condition has certainly become the study of many parties that the function of teachers in this era is to facilitate students so that they can follow the learning process appropriately according to their learning modalities. There are students who can easily receive information from listening to what the teacher explains. Students with this type when the teacher explains the relationship between science and Islam can receive this information easily through listening. There are also students who find it easier to receive lesson information by seeing and reading what they are learning for themselves. Teachers only need to facilitate students with books or other media that students can use to directly see the learning process so that it produces meaning that they can understand. Then there are students who easily receive information by moving. Teachers can facilitate students with a model like this by facilitating learning by means of practicum and others. When teachers understand this learning modality, they will easily relate the relationship between Islam in science materials. In fact, the opposite is true, namely providing the results of scientific studies in strengthening the material in religious lessons in Islamic schools.

In a workshop aimed at promoting the integration of science and religion, we invited science teachers from Islamic schools in three areas of Java: Yogyakarta, Lamongan, and Malang. When asked how they integrate science and religion in their classrooms, most admitted that they did not try it, partly because they felt they had no knowledge of the interpretation to do so, and preferred to avoid the topic and only teach what they were instructed to teach. When asked to develop ways to integrate the curriculum, most teachers propose a similar strategy. They browse online and find verses from the Qur'an that seem relevant to the lesson. At the relevant time they propose to "add paragraph" and then proceed.

However, the apparently simple step to contextualizing scientific facts with the verses of the Qur'an through internet sources contains critical concerns. There is a tendency to label the facts of science in teaching with the verses of the Qur'an. The 
verses of the Qur'an are only affixed to some space in accordance with certain themes in science teaching. Such a model could contain the potential for desacralizing verses of the Qur'an which in turn could lead to new dilemma: contemporary scientific theories could - at any time - be challenged by new scientific theories and evidence. If a theory of science that had previously been linked with a verse from al-Qur'an verses that is sacred and eternal, it is feared that such developments will delegitimize the truth of the verses of the Qur'an. Although this can actually enter the debate of interpretation, for ordinary people can cause prolonged tension and confusion.

This approach not only adds to the burden of teachers in schools (they have to add the curriculum on their own time), but the integration locus is primarily in the minds of teachers, who then must convey the knowledge to the students. This is of course contrary to the objectives of the 2013 curriculum, where teachers should be facilitators, not conveyors, knowledge. In an interesting article on the integration of science and religion, the study of national disaster can offer an appropriate example for the integration of science and religion. ${ }^{21}$ Earthquakes, tsunamis, volcanic eruptions, landslides, erosion, pollution, floods: all are real experiences for many Indonesians, adults and children. ${ }^{22}$ In this context, the problem of integration of scientific and religious explanations of nature is not abstract; they are direct and close to their experience. Such experiences offer children the opportunity to participate in the process of integrating science and religion, not just passively accepting it. Such a real and relevant natural phenomenon can be used to provoke debate among students: What is the relationship between scientific and religious explanations of the phenomenon? Students can propose a variety of interpretations, choose sides and then debate the issue. Playing such a role can be an important part in studying the science discourse ${ }^{23}$, and public discourse in Islam. ${ }^{24}$

Based on these studies, there can be no perfect model of integration of science and Islam. This is because science is not a static phenomenon and is constantly changing based on new discoveries and new interpretations. In Islam, the form of public reasoning also continues to undergo transformation in relation to dynamic developments

${ }^{21}$ Zainal Abidin Bagir, "Nidhal Guessoum's Reconciliation of Islam and Science," Zygon 47, no. 2 (2012): 354-66.

${ }^{22}$ E Yulaelawati and S Usman, Mencerdasi Bencana (Jakarta: PT. Grasindo, 2008).

${ }^{23}$ Richard A Duschl and Jonathan Osborne, "Studies in Science Education Supporting and Promoting Argumentation Discourse in Science Education Supporting and Promoting Argumentation Discourse in Science Education," no. March 2013 (2008): 37-41.

${ }^{24} \mathrm{~J}$ R Bowen, Islam, Law, and Equality in Indonesia: An Anthropology of Public Reasoning (Cambridge University Press., 2003). 
in political, scientific and social change. It is vital that children learn to participate in such debates by inviting them to integrate the integration process into their education. ${ }^{25}$

\section{Design Integration in Learning Objectives of Science}

Basically, in the level of policy the integration of Islamic values in the purpose of learning science has been explicitly stated in the curriculum 2013, namely the Core Competency (KI) 1 which includes the spiritual aspect. There are four Core Competencies (KI) contained in the nationally accepted curriculum, which includes the spiritual aspects (KI 1), social aspects (KI 2), cognitive aspects (KI 3 ) and skill aspects (KI 4). But in its implementation at the educational unit level, each school has different policy determination. In some research-targeted-schools, not all of them implement the 2013 curriculum. Only60\% have implemented the 2013 curriculum (K13), even though the 2013 curriculum policy has been in effect since 2014. Meanwhile, the remaining $40 \%$ of schools still use the old curriculum, Education Unit Level Curriculum known as KTSP curriculum. This is because there is a policy from the Ministry of Education which states that only certain schools are eligible to implement the 2013 curriculumespecially schools that have an "A" accreditation are allowed to use the 2013 curriculum. As for schools with a "B" accreditation still use KTSP curriculum and may gradually start implementing the 2013 curriculum.

Although some schools already use the 2013 curriculum, in fact, the implementation of the 2013 curriculum still cannot be applied maximally. Based on interviews with principals and teachers of science, there has been no curriculum modification in science subjects in terms of content. The curriculum changes from KTSP to the 2013 curriculum mostly have an impact on the addition of the number of hours devoted to the subjects. Curriculum changes have not had any impact on how science is taught. Even where the 2013 curriculum has been implemented in schools, its implementation - in terms of content- still largely makes use of KTSP content. This is also reflected in the learning tools in the form of Learning Implementation Plans that teachers should prepare before the learning activities are implemented.

However, on applying the number of teaching hours at school, some schools modify it by providing by adding additional hours to the expected 5 hours. This is done with the aim to improving students' competence in the field of science. Although this

\footnotetext{
25 Luki "Gulia, "Guru Kaku Sudah Tak Laku," 2013, http://edukasi.kompas.com/read/2013/11/25/1818400/Guru.Kaku.Sudah.Tak.Laku.
} 
adds teaching hours to the subjects does not conflict with the curriculum rules that apply, because basically the application of the 2013 curriculum at the school level is flexible, so it gives flexibility to the schools to modify the curriculum according to the needs of learners in school.

Interestingly even if the school has implemented the 2013 curriculum, but its implementation in classroom learning still deploys conventional instructional techniques rather than the hands-on, student centered learning techniques required by the curriculum (citation here describing instructional techniques in 2013). This is based on interviews with science teachers who stated that the spiritual aspect in KI 1 is seldom elaborated properly and is still a separate part of the implemented lesson. Therefore, the textual form of Islamic integration in science teaching is rarely included in the lesson objectives in the lesson plans actually implemented by the teacher. In science teaching activities, the integration of Islam is almost never explicitly mentioned by the teacher in the learning objectives to be achieved in the material.

\section{Design Integration in Teaching Media Science}

Specifically, there is no school policy regarding the use of instructional media that science teachers should use in teaching. Although at school there are kit and props, they are rarely used by teachers during learning. Based on our observations, science teachers in two schools also occasionally use audio visual media to explain the science materials. However, the use of such media only occurs in the context of certain lessons only. Usually science teachers use the internet to download video or animated images related to the material to be delivered. The teacher uses the video as an apperception: a way of linking students experience with the new ones in the science lesson. In another school we observed, if teachers want to use audio-visual media in delivering the material, they must usually reserve a multimedia classroom whose use must be authorized by the manager of school infrastructure.

The average of science teaching media available in Islamic schools in Java are limited, but science teachers work around this by making simple teaching media. For example, the use of secondhand items as a teaching medium or also one that has been done is to bring the plants to be observed in the classroom. The making of science teaching media is typically done solely by teachers on their own initiative in accordance with the science material presented. There are also schools in which the manufacture of simple teaching media is carried out by students on the teacher's instructions. For 
example, in order to learn about the chemical content of fabric is by doing a simple laboratory test. Students bring their own rags, which are then identified in a group in the classroom. The identification of the chemical content is done by burning the fibers with teacher supervision. Another form of identification is by sniffing the cloth, to determine whether it contains natural or artificial fibers.

Specifically, the instructional media used by teachers to integrate Islam in science teaching is typically by using downloaded videos from YouTube. The media is used by the teacher as an apperception activity and also inserts it in concluding the material at the end of the lesson. In addition, the Islamic integration program has also become a school program in the form of placing the written media in certain parts of the school. The writing typically in the form of verses of the Qur'an that are related to science.

\section{Design Integration in Science Teaching Methods}

Like most schools in Indonesia, in general the Islamic schools in our Javanese sample seek to apply student-oriented rather than lecture oriented learning methods as directed to the Curriculum 2013. Nevertheless, many of the teaching methods used by teachers in teaching science are still largely tutorial and lacking in practice. For example, in Islamic schools in Lamongan there is no policy from the principal in determining the standard methods used in science teaching. The selection of teaching methods is entirely left to each teacher. Teachers mostly apply lecture methods, discussions, occasional assignments, demonstrations, and very little experimentation in the laboratory. This is due to the inadequacy of laboratory facilities and limited infrastructure in schools, even tend not to use the existing equipment.

In some Islamic schools the subject of research has made efforts to integrate Islamic values in science teaching Textually not written in lesson plan and books, but in practice teachers have inserted Islamic values in science teaching in accordance with their abilities. The integration of Islamic values in science teaching is still delivered typically using the lecture method by linking the Qur'an verses that are inserted into the material being studied. For example, when teaching about the solar system, a teacher may quote the al-Qur'an letter of Ali Imron in verses 190-191, which describe the how God created day and night, heaven and earth and all its contents. However, not all science teachers are able to quote directly verses of the Qur'an that are in accordance with the material because of the limited ability of teachers to master the verses of the 
Qur'an. Instead, teachers usually associate lessons with general attitudes (e.g an attitude of gratitude) rather than specific Qur'anic verses.

\section{Design Integration in the Evaluation of Science Learning}

Evaluation of science teaching conducted by teachers is generally based on three aspects, namely cognitive, affective and psychomotor. Assessment of students' ability in the cognitive domain is done through various forms. For example, by giving a pretest at the beginning of a unit and posttest at the culmination of the material. This is done to determine the level of understanding of students both before and after the material delivered. Another form of evaluation is usually with a direct question after the material has been delivered is formative assessment. The teacher tells the students to close the book, prepare the paper, and answer every question the teacher asks. In this way the student will answer according to his ability, because it will not have a chance to cheat. Students are then evaluated, depending on the number and type of questions most students cannot answer. So on the next occasion the teacher to review material that by many students have not understood it.

The learning evaluation system applied by the science teacher starts from doing the material review at the beginning of each learning, then continued the questioning in the middle of the lesson, at the end if possible still have time usually given the questions. The teacher develops a test and a test system in accordance with the study material presented, if in the material demands to conduct the assessment in the form of a practicum, then the teacher does practicum, but if the assessment is enough with the study of the theory, then tests are given in the form of giving questions to students. In addition to these evaluations, the evaluation of science is also done through the Midterm exam and Final exams. In the Midterm exam teachers can adjust the test problems related to the material that have been taught to the students, because the one who makes the Midterm exam question is the science teacher himself in his own school. But since the final exam is a group product resulting from the Teachers Academic Subject Meeting called MGMP for science subject, the problem is more diverse. As for the affective aspect, it is assessed through the attitude of students during the science lesson. Then for the psychomotor aspect the assessment is done during the practicum as well as the students do the discussion activities in the learning.

There is no Islamic integration done by teachers when doing science teaching evaluation. Teachers only conduct evaluation in accordance with aspects of assessment 
in science teaching. The majority of teachers were concerned that if the evaluation activities included the integration of Islam it would be difficult for students.

\section{Conclusion}

The integration of Islam in science teaching has been implemented by several Islamic schools in Java, Indonesia. But the pattern of integration that most teachers do is to quote verses of the Qur'an relating to the material being studied. Their strategy is to browse online and find verses from the Qur'an relevant to the material being studied. Another form of integration that is done is the placement of media images or writing on the school wall that contains verses of the Qur'an related to science. Although the implementation of the teacher has been integrated, but not yet documented in the Lesson Plans and science learning evaluation system.

\section{References}

Amelia, Trisna, and Inelda Yulita. "Desain Pembelajaran Berbasis Literasi Sains Dan Berwawasan Kemaritiman Sebagai Hasil Pelatihan Di SMAN 4 Tanjungpinang." Jurnal Anugerah 1, no. 1 (2019): 25-31. https://doi.org/10.31629/anugerah.v1i1.1580.

Aulia, Luki. "Guru Kaku Sudah Tak Laku," 2013. http://edukasi.kompas.com/read/2013/11/25/1818400/Guru.Kaku.Sudah.Tak.Laku.

Bagir, Zainal Abidin. "Nidhal Guessoum's Reconciliation of Islam and Science.” Zygon 47, no. 2 (2012): 354-66.

Barbour, Ian G. When Science Meets Religion. New York: Harper San-Fracisco, 2000.

Bowen, J R. Islam, Law, and Equality in Indonesia: An Anthropology of Public Reasoning. Cambridge University Press., 2003.

Duschl, Richard A, and Jonathan Osborne. "Studies in Science Education Supporting and Promoting Argumentation Discourse in Science Education Supporting and Promoting Argumentation Discourse in Science Education," no. March 2013 (2008): 37-41.

Gary R. Morrison, Steven M. Ross, Howard K. Kalman, \& Jerrold E. Kemp. Designing Effective Instruction 7th Edition. Indiana: Jon Wiley \& Sons.Ind., 2013.

Ghofur, Abdul, Nahdia Rupawanti Br, and Abdul Kholid Achmad. "Instructional Management Strategy: A Multi-Sites Study on Science Teaching for Islamic School" 3, no. 3 (2017): 211-17.

Gustina, S I. Pengembangan Desain Pembelajaran Tematik Outdoor Permainan Tradisional Berbasis STEM Di Sekolah Dasar. Universitas Pendidikan Indonesia Kampus Tasikmalaya, 2018.

Hasanah, Nur, and Anggun Zuhaida. "Desain Madrasah Sains Integratif: Integrasi Sains Dan Agama Dalam Perangkat Dan Pelaksanaan Pembelajaran." Edukasia : Jurnal $\begin{array}{lllllll}\text { Penelitian Pendidikan Islam 13, no. } 1 & \text { (2018): } 155 .\end{array}$ 
https://doi.org/10.21043/edukasia.v13i1.3517.

Heryanto, A. Identitas Dan Kenikmatan: Politik Budaya Layar Indonesia. Jakarta: Kepustakaan Populer Gramedia, 2015.

Isya', Muhammad Andi. "Pengembangan Model Pembelajaran Instruksional Design Dengan Model Addie Mata Pelajaran PAI Pada Materi Mengulang-Ulang Hafalan Surah Al Ma'un Dan Al Fil Secara Klasikal, Kelompok Dan Individu Kelas V SDN Gedongan 2 Kota Mojokerto." Ta'dibia: Jurnal Ilmiah Pendidikan Agama Islam 7, no. 1 (2017): 71. https://doi.org/10.32616/tdb.v7i1.37.

Jones, C. "Images of Desire: Creating Virtue and Value in an Indonesian Islamic Lifestyle Magazine.” Journal of Middle East Women's Studies 6 (2010): 91-117.

Lestari, Iing Dwi. "Pengaruh Literasi Sains Terhadap Kemampuan Kognitif Siswa Pada Konsep Ekosistem." Prosiding Seminar Nasional Pendidikan FKIP UNTIRTA 2017, 2017, 103-6.

Lubis, M. A. \& Azizan, N. Pembelajaran Tematik SD/MI. Yogyakarta: Samudra Biru, 2019.

Nisa Khairun, and Rudianto. "Trend Fashion Hijab Terhadap Konsep Diri Hijabers Komunitas Hijab Medan.” Jurnal Interaksi 1, no. 1 (2017): 105-17.

Oktapiani, Nida, and Ghullam Hamdu. "Desain Pembelajaran STEM Berdasarkan Kemampuan 4C Di Sekolah Dasar." Jurnal Ilmiah Pendidikan Dasar 7, no. 2 (2020): 99. https://doi.org/10.30659/pendas.7.2.99-108.

Purwanto, Agus. Nalar Ayat-Ayat Semesta. Bandung: Mizan, 2015.

Reigeluth, Charles M. "Instructional Theory and Technology for the New Paradigm of Education." Revista de Educación a Distancia, no. 50 (2016): 1-18. https://doi.org/10.4324/9781315760933.

Rozy, Yahya Fathur. "Data Populasi Penduduk Muslim 2020: Indonesia Terbesar Di Dunia.” Ibtimes.id, 2020. https://ibtimes.id/data-populasi-penduduk-muslim-2020indonesia-terbesar-di-dunia/.

Sugiyono. Metode Penelitian Kuantitatif, Kualitatif, $R \& D$. Bandung: CV. Alfabeta, 2017.

Waston. "Hubungan Sains Dan Agama: Refleksi Filosofis Atas Pemikiran Ian G. Barbour.” PROFETIKA, Jurnal Studi Islam 15, no. 1 (2014): 76-89.

Yulaelawati, E, and S Usman. Mencerdasi Bencana. Jakarta: PT. Grasindo, 2008.

Zuhri, Misbah Khoiruddin. "Spiritualitas Sains Modern: Pembacaan Terhadap Relasi Agama Dan Sains.” JURNAL PENELITIAN 14, no. 2 (2017): 183-200. 